Tópico de Interesse Geral

\title{
Aspectos histológicos da pele de cães e gatos como ferramenta para dermatopatologia ${ }^{1}$
}

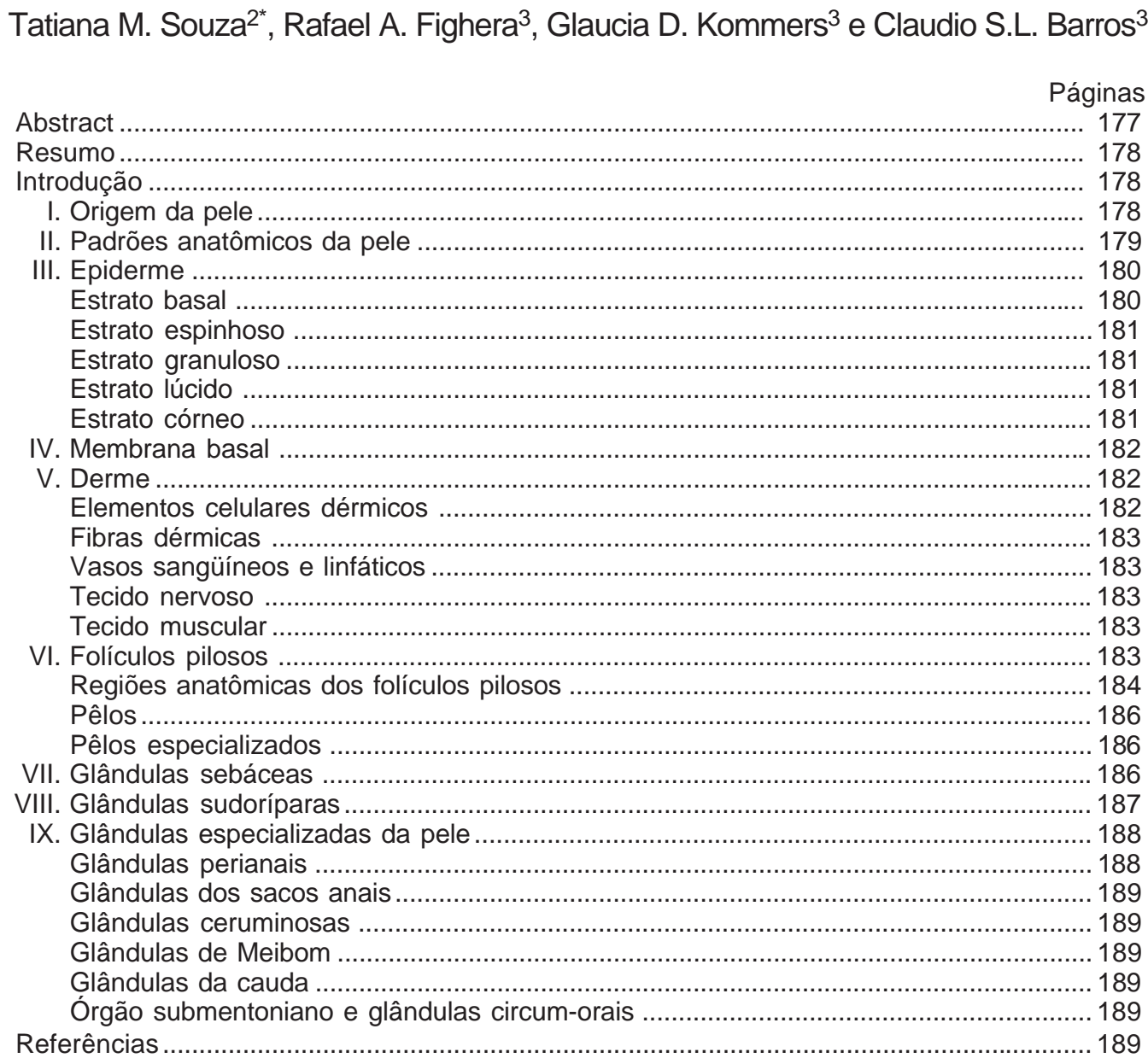

ABSTRACT.- Souza T.M., Fighera R.A., Kommers G.D. \& Barros C.S.L. 2009. [Histological aspects of canine and feline skin as a tool for dermatopathology.] Aspectos histológicos da pele de cães e gatos como ferramenta para dermatopatologia. Pesquisa Veterinária Brasileira 29(2):177-190. Departamento de Patologia, Universidade Federal de Santa Maria, 97105-900 Santa Maria, RS, Brazil. E-mail: teitsouza@yahoo.com.br

Skin morphology differs among different animal species and most part of our knowledge on the morphology of human skin can not be applied for dogs and cats. Thus, the

\footnotetext{
${ }^{1}$ Recebido em 17 de outubro de 2008.

Aceito para publicação em 24 de novembro de 2008.

Parte da Tese de Doutorado do primeiro autor.

2 Programa de Pós-Graduação em Medicina Veterinária, área de concentração em Patologia Veterinária, Centro de Ciências Rurais (CCR),
} Universidade Federal de Santa Maria (UFSM), Av. Roraima 1000, Ci-
dade Universitária, Camobi, Santa Maria, RS 97105-900, Brasil. *Autor
para correspondência: teitsouza@yahoo.com.br
3 Departamento de Patologia, Centro de Ciências da Saúde (CCS),
UFSM, Camobi, Santa Maria, RS 97105-900, Brasil. 
understanding of the basic morphologic aspects of the skin from different species is an invaluable tool for every professional in the field of veterinary pathology. Furthermore, the ability to recognize the main similarities and main differences in the skin morphology from different anatomical signs within the same animal is fundamental to the practice dermatopathology. This paper reviews the major aspects of the microscopic anatomy of the skin in dogs and cats, aiming to help those veterinary pathologists that are starting in the field of dermatopathology, since only with the knowledge of the peculiarities of this organ it will be possible to apply the diagnostic approach through lesion patterns.

INDEX TERMS: Morphology, histology, pathology, dermatopathology, skin, dogs and cats.

RESUMO.- A pele não é histologicamente igual nas diferentes espécies animais. Muito do que se sabe sobre a morfologia da pele humana não pode ser aplicado para cães e gatos. Dessa forma, o conhecimento dos aspectos histológicos básicos da pele nas diferentes espécies se faz necessário para todo profissional da área da patologia veterinária. Além disso, o reconhecimento das principais semelhanças e diferenças estruturais da pele em diferentes regiões do corpo desses animais é fundamental para o exercício da dermatopatologia. Este artigo revisa os principais aspectos da anatomia microscópica da pele de cães e gatos, a fim de auxiliar aqueles patologistas veterinários que estão iniciando no campo da dermatopatologia, pois somente com o reconhecimento das características peculiares desse órgão será possível compreender o método de diagnóstico através de padrões de lesão.

TERMOS DE INDEXAÇÃO: Morfologia, histologia, patologia, dermatopatologia, pele, cães e gatos.

\section{INTRODUÇÃO}

Atualmente, a dermatopatologia é uma das áreas da patologia veterinária que mais cresce no Brasil (Werner 2008). Como ocorreu nas décadas de 1980 e 1990 nos Estados Unidos (Affolter \& Moore 1994), isso reflete o aumento gradativo no número de profissionais que estão se dedicando à dermatologia de pequenos animais e a conscientização de que o exame histopatológico é uma ferramenta importante na realização do diagnóstico das doenças que afetam a pele de cães e gatos. Nos últimos anos, muitos laboratórios de patologia veterinária do país tiveram um aumento gradativo em sua rotina dermatopatológica, o que tem feito com que cada vez mais iniciantes em patologia veterinária demonstrem interesse por essa área.

Como ocorre na patologia de todos os sistemas, os aspectos morfológicos fundamentais da pele devem ser conhecidos para que suas alterações possam ser mais bem compreendidas. Segundo dois dos mais renomados dermatopatologistas norte-americanos "é muito importante que o patologista esteja familiarizado com a estrutura normal da pele, não apenas nas diferentes espécies, mas, também, nas diferentes localizações anatômicas" (Yager \& Scott 1993). Essa é uma linha de pensamento que vem ganhando força através da publicação de livros de histologia que têm patologistas como público alvo, como o Histology for Pathologist (Sternberg 1997) e o Histology and Cell Biology: An introduction to pathology (Kierszen-baum 2006).
Com base nesses fatos, o objetivo deste artigo é revisar as principais características da anatomia microscópica da pele de cães e gatos, a fim de auxiliar aqueles patologistas veterinários interessados na dermatopatologia, pois somente com o reconhecimento das estruturas normais desse órgão é possível compreender o método de diagnóstico através dos padrões de lesão, adaptado da dermatopatologia humana (Ackerman 1978) para a dermatopatologia veterinária (Gross et al. 1992).

\section{ORIGEM DA PELE}

A epiderme desenvolve-se a partir do ectoderma e a derme origina-se do mesoderma (Kristensen 1975). No feto, a epiderme é inicialmente formada por uma camada de células epiteliais cúbicas, mas, à medida que essas células proliferam, ocorre estratificação (Banks 1992). Outras células que formam a epiderme como os melanócitos e as células de Langerhans, originam-se da crista neural e da medula óssea, respectivamente (Kierszenbaum 2006).

A derme desenvolve-se a partir da proliferação de células mesenquimais primitivas (Monteiro-Riviere et al. 1993). Com o desenvolvimento do feto, esse tecido primitivo sofre maturação para formar a derme do recém-nascido. O processo de amadurecimento dérmico inclui principalmente o aumento da espessura e do número de fibras colágenas, a substituição gradual do colágeno tipo III pelo colágeno tipo I, a redução da substância fundamental e a diferenciação de células mesenquimais precursoras em fibroblastos (Scott et al. 2001).

A proliferação do epitélio cúbico formador da epiderme dá origem a aglomerados de células basofílicas denominados germes epiteliais primários ou germes do pêlo e sua invaginação para a derme subjacente, na forma de um cordão celular, resulta nos folículos pilosos e nas glândulas anexas, cujas células se mantêm continuas com os estratos da epiderme (Banks 1992). O cordão celular forma um canal dérmico que permite que o restante da epiderme se continue para formar a futura bainha radicular externa (Monteiro-Riviere et al. 1993). Essa bainha dá origem à matriz germinativa na base do folículo piloso, que, por sua vez, forma a bainha radicular interna e o pêlo (Banks 1992). O estímulo para essa migração celular é induzido pela sinalização de moléculas derivadas dos fibroblastos mesodérmicos da futura derme. Logo abaixo do aglomerado inicial de células basais, os fibroblastos dérmicos for- 
mam um pequeno nódulo, a papila dérmica. Com o desenvolvimento do folículo piloso, a papila dérmica se projeta para o centro da área de brotamento e torna-se circundada por um aglomerado de células epiteliais, que dão à base do folículo piloso um aspecto dilatado, denominado bulbo folicular (Kierszenbaum 2006).

\section{PADRÕES ANATÔMICOS DA PELE}

Em geral, a pele possui quatro padrões anatômicos que diferem em vários aspectos, mas, principalmente, em relação à espessura. Esses padrões incluem pele com pêlos (Fig.1), pele escrotal (Fig.2), coxins (Fig.3) e plano nasal (Fig.4) (Yager \& Wilcock 1994).

A pele com pêlos caracteriza-se por possuir uma espessura variável $(0,5-5 \mathrm{~mm}$ no cão e $0,4-2 \mathrm{~mm}$ no gato) (Strickland \& Calhoun 1963, Scott 1980, Affolter \& Moore 1994). A espessura cutânea diminui no sentido dorso ven-
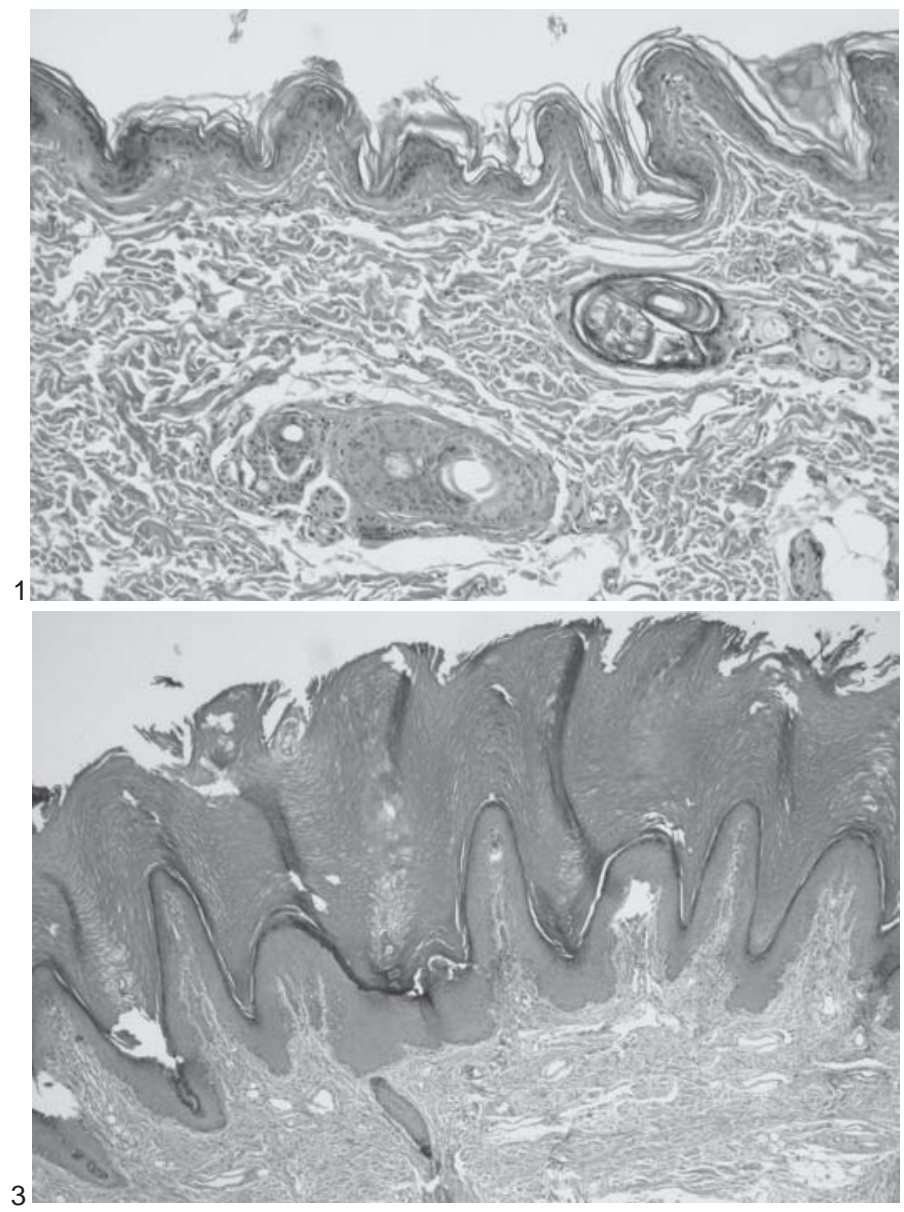

Fig.1. Pele com pêlos (Cão). A epiderme é delgada e levemente ondulada. HE, obj.4x.

Fig.3. Pele do coxim (Cão). A espessura da epiderme decorre, em grande parte, da pronunciada espessura do estrato córneo. HE, obj.4x.

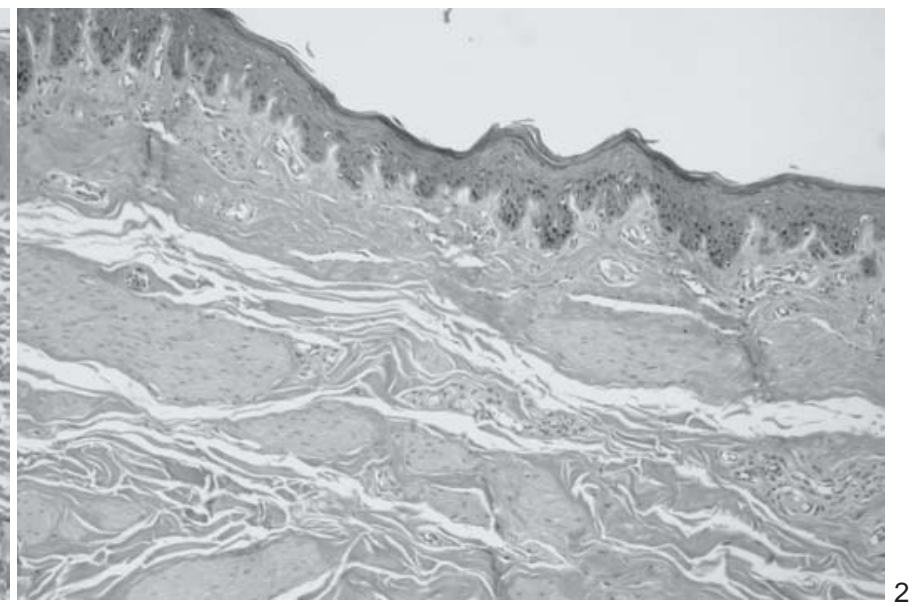

tral do tronco e no sentido proximal-distal dos membros (Webb \& Calhoun 1954, Lovell \& Getty 1957, Strickland \& Calhoun 1963, Kristensen 1975), ou seja, a pele do dorso, do pescoço (Affolter \& Moore 1994) e da cabeça (Webb \& Calhoum 1954) é mais espessa que a pele do abdômen. Além disso, a pele é mais espessa na fronte, na região glútea e na base da cauda e mais fina nos paviIhões auriculares e nas regiões axilar, inguinal e perianal (Webb \& Calhoun 1954, Lovell \& Getty 1957). A pele do escroto é considerada a mais fina do corpo, já a dos coxins e a do plano nasal são acentuadamente espessas (Affolter \& Moore 1994). Além das diferenças na espessura entre as diferentes regiões da pele, podem ocorrer variações relacionadas com a idade e a raça de cães e gatos (Kristensen 1975).

A arquitetura básica da epiderme é semelhante em todos os mamíferos, mas existem diferenças entre o ho-

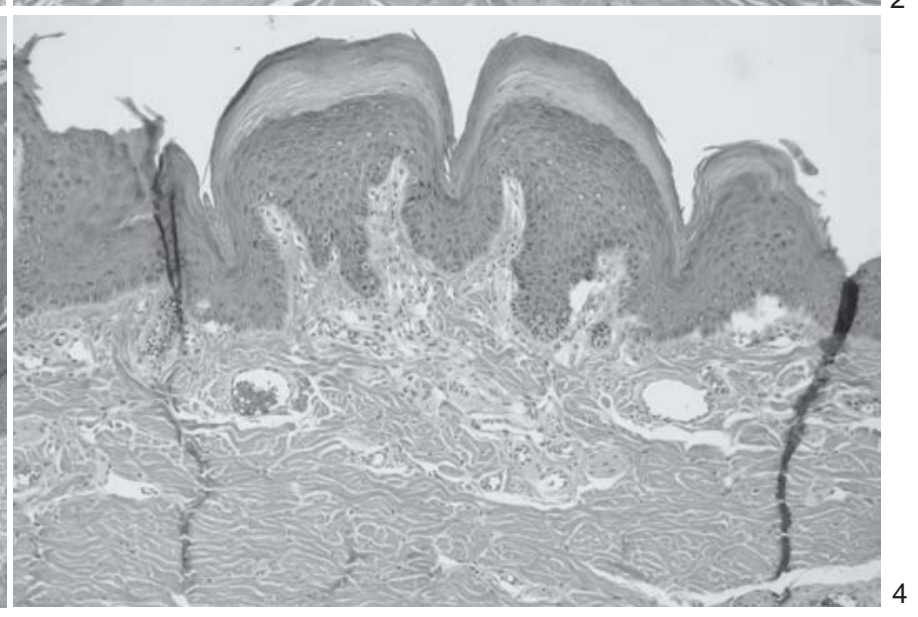

Fig.2. Pele do escroto (Cão). Observe as cristas da rede e as fibras do músculo liso da túnica dartos entremeadas às fibras de colágeno na derme superficial, uma característica típica desta região da pele. HE, obj.4x.

Fig.4. Pele do plano nasal (Cão). Observe o espesso estrato córneo, a intensa formação de cristas da rede, a presença de vasos sangüíneos e nervos proeminentes e a ausência de anexos cutâneos. HE, obj.4x. 
mem e os animais, entre as diferentes espécies animais, entre indivíduos da mesma espécie e entre as diferentes regiões do corpo de um mesmo indivíduo (Montagna 1967, Meyer et al. 1978). Na pele com pêlos há uma relação inversa entre a espessura da epiderme e a densidade da pelagem, portanto, a epiderme dos mamíferos peludos é muito mais fina do que a de humanos (Affolter \& Moore 1994). No cão, a epiderme, em geral, consiste de duas a três camadas de células nucleadas (Webb \& Calhoun 1954, Strickland \& Calhoun 1963, Lloyd \& Garthwaite 1982), mas pode atingir até 10 camadas de células nucleadas em determinados locais (Scott et al. 2001). O gato possui uma epiderme ainda mais fina que a do cão (Scott 1980). De qualquer forma, independentemente do número de camadas, não há cristas da rede (cristas interpapilares ou rete ridges) na pele com pêlos de cães e gatos (Yager \& Wilcock 1994).

A pele do escroto, dos coxins e do plano nasal caracteriza-se por uma epiderme muito mais espessa do que a observada na pele com pêlos e por possuir cristas da rede conspícuas. Nesses três locais, a espessura é dada pelo maior número de camadas do estrato espinhoso. Entretanto, nos coxins e no plano nasal, boa parte dessa característica se deve também ao espesso estrato córneo compacto e laminado, respectivamente (Yager \& Wilcock 1994). No gato, a epiderme da pele com pêlos pode ter tão somente 25Pm de espessura, enquanto que a epiderme dos coxins e do plano nasal pode ter até 900Pm de espessura (Yager \& Scott 1993). Muitos valores foram estabelecidos para a espessura da epiderme da pele com pêlos de cães e gatos, mas, em geral, ela nunca excede $100 \mathrm{zm}$. Em média, a espessura da epiderme dessas duas espécies varia entre 15 e $40 \mathrm{zm}$, com os gatos tendo o valor mais baixo e os cães a média superior (Kristensen 1975). Em um estudo, em que foi avaliada a pele de 13 cães sem raça definida, a epiderme foi considerada fina ou espessa com base em um limite de até $100 \mathrm{zm}$ de espessura. Os resultados desse estudo demonstraram que a epiderme mais fina encontra-se no esterno, com $26,5 \mathrm{zm}$, e a mais espessa no coxim, com $1.685 \mathrm{zm}$. Todas as outras áreas avaliadas foram caracterizadas por uma epiderme fina. Embora a pele do plano nasal não tenha sido avaliada nesse estudo (Webb \& Calhoum 1954), outros autores determinaram a espessura do plano nasal como tendo aproximadamente $1.500 \mathrm{zm}$ (Affolter \& Moore 1994).

Na pele com pêlos, o número e o tamanho das estruturas anexas variam com o local do corpo, mas, no geral, há uma quantidade de unidades pilossebáceas muito maior do que a observada na pele do escroto. Nos coxins e no plano nasal não há unidades pilossebáceas (Affolter \& Moore 1994). Algumas outras características anatômicas marcantes de cada uma dessas regiões incluem: (1) abundante quantidade de feixes de fibras do músculo liso da túnica dartos entremeados com fibras colágenas e elásticas da derme do escroto (Monteiro-Riviere et al. 1993), (2) presença de glândulas sudoríparas écrinas nos coxins
(Banks 1992, Scott et al. 2001, Dunstan 2002) e (3) presença de vasos sangüíneos e nervos proeminentes e ausência de anexos cutâneos no plano nasal (Yager \& Wilcock 1994).

\section{EPIDERME}

A epiderme, a camada mais externa da pele, é constituída por um epitélio estratificado, pavimentoso e ceratinizado, e subdividida em estrato basal (estrato germinativo), estrato espinhoso, estrato granuloso, estrato lúcido e estrato córneo (estrato disjunto) (Webb \& Calhoun 1954). A espessura, o tipo de camada córnea e a presença ou ausência do estrato lúcido são influenciados pela densidade da pelagem (Montagna 1967). A epiderme é constituída por quatro tipos celulares: ceratinócitos, melanócitos, células de Langerhans e células de Merkel (Bacha \& Wood 1990, Banks 1992, MonteiroRiviere et al. 1993). A quantidade de cada uma dessas células é variável, mas aproximadamente $85 \%$ delas são ceratinócitos, 5\%-8\% são melanócitos e 5\% são células de Langerhans (Yager \& Scott 1993). Os ceratinócitos migram constantemente para formar os diferentes estratos epidérmicos (Banks 1992, Monteiro-Riviere et al. 1993) de modo que o estrato basal é o berço das células da epiderme e a ceratina é o produto da diferenciação dos ceratinócitos basais (Scott et al. 2001). Assim, a epiderme é uma estrutura dinâmica constantemente renovada pela descamação do estrato córneo (Kristensen 1975). Alguns autores consideram que a diferenciação final da epiderme em estrato córneo é uma forma especializada de apoptose (McCall \& Cohen 1991, Polakowska et al. 1994).

\section{Estrato basal}

As células do estrato basal se dispõem em uma única fileira e possuem forma cúbica ou cilíndrica. Essa camada repousa sobre a membrana basal e é considerada o ponto de separação dermo-epidérmico (Bacha \& Wood 1990, Banks 1992, Monteiro-Riviere et al. 1993, Bal 1996). Por haver intensa proliferação celular no estrato basal, é normal que sejam observadas células em mitose e células em apoptose (Scott et al. 2001). Em áreas esparsamente peludas ou glabras (sem pêlos), o índice mitótico é maior, pois essas áreas estão sujeitas a escoriações e necessitam de um maior pool de células para repor o estrato córneo (Montagna 1971). Células em apoptose são vistas na microscopia de luz como células isoladas com citoplasma eosinofílico e brilhante e com núcleo fragmentado ou picnótico (Urmacher 1997).

O estrato basal é o local onde estão os corpos celulares dos melanócitos e, dessa forma, esses também podem ser vistos na bainha radicular externa e nos ductos das glândulas sebáceas e sudoríparas (Scott 1980). De acordo com sua localização, os melanócitos podem ser classificados em epidérmicos e foliculares (Guaguère 1985). Cada melanócito emite várias extensões citoplasmáticas denominadas dendritos, a fim de estabelecer contato direto com os ceratinócitos do estrato espinhoso, for- 
mando as unidades epidermomelânicas (Kierszenbaum 2006). No cão e no gato, há, em média, um melanócito para cada 10 a 20 ceratinócitos (Affolter \& Moore 1994). Em gatos os melanócitos intraepidérmicos são mais esparsos, com exceção do escroto, prepúcio, mamilos e pele circum-anal (Affolter \& Moore 1994).

Sob a denominação melanina encontra-se uma gama de pigmentos (eumelanina, feomelanina, etc...) (MonteiroRiviere et al. 1993), qu!e variam de marrom-amarelado a marrom-escuro, produzidos pelos melanócitos a partir do aminoácido tirosina (Scott et al. 2001). O termo melanina vem do grego melas, que significa preto (Dorland 1999). O mecanismo bioquímico da produção de melanina depende da ação da enzima tirosinase, que oxida tirosina em 3,4 diidroxifenilalanina (DOPA), metabólito que então é transformado em melanina (Burchill 1991).

A melanina produzida pelos melanócitos é estocada em grânulos citoplasmáticos (melanossomas) e transferida para os ceratinócitos por um complexo processo conhecido como secreção citócrina ou citocrinia (Kierszenbaum 2006). Os melanossomas acumulam-se no citoplasma dos ceratinócitos, principalmente ao redor do núcleo (Banks 1992, Monteiro-Riviere et al. 1993, Bal 1996). O pigmento melanina é particularmente importante na pele, pois protege as células dos raios ultravioletas do sol (Montagna 1971, Banks 1992, Bal 1996, Bragulla et al. 2004).

O aumento na pigmentação em algumas raças é devido ao aumento no número dos melanossomas que se estendem para os estratos mais superiores da epiderme (Affolter \& Moore 1994). Na derme, pode ser encontrada uma segunda população de células contendo melanina os melanófagos - que fagocitam a melanina que adentrou a derme secundariamente à destruição dos melanócitos epidérmicos ou foliculares (Scott et al. 2001).

As células de Merkel estão confinadas ao estrato basal, ocorrem apenas nos coxins tilotríquios e funcionam como mecanorreceptores (Affolter \& Moore 1994). Coxins tilotríquios (corpúsculo de toque, corpúsculos de Pinkus ou haarscheiben) são estruturas pequenas, com 0,16$0,42 \mathrm{~mm}$ de diâmetro, e sem pêlos que estão presentes na pele com pêlos de cães e gatos. Essas células estão unidas aos ceratinócitos e mantêm contato com fibras nervosas que se projetam da derme para epiderme. As fibras nervosas são mielinizadas, mas tornam-se amielínicas após ultrapassar a lâmina basal da epiderme e expandem-se em uma terminação sensitiva na forma de uma placa nervosa que está em contato com a célula de Merkel (Kühnel 2005). Embora a origem embrionária dessas células permaneça indefinida (Urmacher 1997), elas possuem características imunoistoquímicas que sugerem uma diferenciação epitelial e neural (Scott et al. 2001).

\section{Estrato espinhoso}

O estrato espinhoso está logo acima do estrato basal e consiste de um número variável de camadas, de acordo com a região do corpo (Bacha \& Wood 1990, Banks 1992, Monteiro-Riviere et al. 1993). Suas células passam de cúbicas ou cilíndricas a pavimentosas e estão ligadas entre si por pontes intercelulares (Banks 1992, Monteiro-Riviere et al. 1993, Scott et al. 2001). O fato dessas células se contraírem durante o processamento histológico, deixando "pontes" citoplasmáticas presas aos desmossomas, ocasiona o aspecto de espinho que confere a denominação ao estrato (Bal 1996, Hargis \& Ginn 2007). Nesse estrato estão localizadas as células de Langerhans, que em muitas espécies, com exceção do cão, possuem grânulos de Birbeck (Bal 1996, Scott et al. 2001). Essas células originam-se da linhagem monocítica e funcionam como apresentadoras de antígeno na pele (Banks 1992, Hargis \& Ginn 2007). Em conjunto com os linfócitos T epidermotrópicos, as células de Langerhans formam o tecido linfóide associado à pele (Hargis \& Ginn 2007).

\section{Estrato granuloso}

O estrato granuloso é formado por uma ou várias camadas de células rombóides ou pavimentosas que possuem grânulos de cerato-hialina (Bacha \& Wood 1990, Banks 1992, Monteiro-Riviere et al. 1993, Bal 1996). Esses grânulos são ricos em filagrina, um filamento protéico não-intermediário (Kierszenbaum 2006) que atua como substância interfibrilar da ceratina mole (Banks 1992, Monteiro-Riviere et al. 1993), permitindo sua agregação (Kierszenbaum 2006). O estrato granuloso não está presente em todos os cortes histológicos da pele com pêlos (Grau \& Walter 1975). Na pele das regiões mandibular e temporal, do dorso da cabeça, do ouvido externo (Webb \& Calhoum 1954) e do plano nasal (Affolter \& Moore 1994), o estrato granuloso é fino ou ausente. Diferentemente dessas áreas, o estrato granuloso dos coxins é bem desenvolvido (Affolter \& Moore 1994).

\section{Estrato lúcido}

O estrato lúcido é constituído por camadas de células pavimentosas, translúcidas e anucleadas (Bacha \& Wood 1990, Banks 1992, Monteiro-Riviere et al. 1993), que não mais possuem grânulos de cerato-hialina, apenas uma substância chamada eleidina (Banks 1992, MonteiroRiviere et al. 1993). Em cães e gatos, esse estrato ocorre somente nas regiões mais espessas da pele, como coxins e plano nasal (Bacha \& Wood 1990, Banks 1992, MonteiroRiviere et al. 1993, Affolter \& Moore 1994, Bal 1996). Para alguns autores, o estrato lúcido é apenas um artefato de refração de células córneas jovens (Bragulla et al. 2004).

\section{Estrato córneo}

O estrato córneo é formado por várias camadas de células ceratinizadas e anucleadas - os corneócitos - (Bacha \& Wood 1990, Banks 1992) e varia em espessura de 3$35 \mathrm{Pm}$ em gatos e de 5-1.500Pm em cães (Scott et al. 2001). A descamação gradual desse estrato é equilibrada pela proliferação de células basais (Scott et al. 2001).

A ceratina é uma proteína composta por microfibrilas, com baixo teor de enxofre, imersas em uma matriz amorfa, rica em enxofre (Banks 1992). Existem dois tipos de 
ceratina; a mole, presente na epiderme e em algumas mucosas, e a dura, típica dos anexos cutâneos (por exemplo, pêlos e unhas) (Bragulla et al. 2004).

Nos estratos lúcido e córneo, os filamentos intermediários de ceratina são unidos por ligações cruzadas com a filagrina e esse complexo (complexo ceratina-filagrina) é depositado na face interna da membrana plasmática, formando o chamado envoltório celular cornificado. Esse processo leva ao achatamento dos ceratinócitos, uma característica morfológica típica desses dois estratos epidérmicos. O envoltório celular cornificado é reforçado por outras proteínas (involucrina, loricrina e pequenas proteínas ricas em prolina), que se mantêm unidas por ligações cruzadas de várias transglutaminases e depositam-se imediatamente abaixo da membrana plasmática. Externamente, os ceratinócitos do estrato córneo são envoltos por um complexo de lipídios liberados dos grânulos lamelares para o espaço extracelular. Esses lipídios, principalmente o glicolipídio acilglicosilceramida, ligamse a involucrina para formar o complexo do envoltório celular cornificado composto, que é responsável por uma das funções mais importantes da pele, a formação de uma barreira impermeável a líquidos, chamada barreira de permeabilidade da epiderme (Kierszenbaum 2006).

\section{MEMBRANA BASAL}

A membrana basal é responsável pela separação dermoepidérmica e fixa a epiderme na derme, mantendo a arquitetura da pele. Na microscopia de luz, em cortes corados pela hematoxilina-eosina (HE), a zona da membrana basal é de difícil identificação. Em cortes corados pelo ácido periódico de Schiff (PAS), essa zona pode ser visível (Kristensen 1975, Monteiro-Riviere et al. 1993), principalmente nos coxins, no plano nasal e nas junções mucocutâneas de cães e gatos (Affolter \& Moore 1994). Ultraestruturalmente, a membrana basal pode ser dividida em quatro componentes básicos: membrana plasmática da célula basal (com hemidesmossomas e filamentos de ancoragem), lâmina lúcida ou lâmina rara (composta de laminina), lâmina densa ou lâmina basal (composta de colágeno tipo IV) e área da sublâmina densa ou lâmina fibroreticular (composta de fibrilas de ancoragem e microfibrilas) (Urmacher 1997).

\section{DERME}

A derme ou córion tem origem mesodérmica e está separada da epiderme pela membrana basal (Banks 1992, Bragulla et al. 2004). A derme humana é dividida em derme papilar (ou superficial) e derme reticular (ou profunda). A derme papilar se interdigitaliza com a epiderme através das papilas dérmicas e epidérmicas (Kühnel 2005, Kierszenbaum 2006). A derme reticular localiza-se entre a derme papilar e o tecido subcutâneo (McKee 1999). Como na pele com pêlos de cães e gatos não há cristas da rede e, portanto, não há papilas dérmicas, a utilização desses termos é imprópria nessas duas espécies
(Kristensen 1975). Entretanto, alguns autores dividem a derme dos animais da mesma forma como é feito para derme humana (Grau \& Walter 1975, Bacha \& Wood 1990, Monteiro-Riviere et al. 1993). Mais corretamente, a derme dos cães e gatos é dividida em superficial e profunda (Affolter \& Moore 1994, Scott et al. 2001).

A derme é formada por tecido conjuntivo, principalmente na forma de fibras entrelaçadas, pelos elementos celulares dérmicos e pelos apêndices epidérmicos, ou seja, folículos pilosos e glândulas anexas (Banks 1992, Bragulla et al. 2004, Hargis \& Ginn 2007). Na derme estão localizados vasos sangüíneos, vasos linfáticos, nervos e músculo liso (músculo eretor do pêlo) (Banks 1992, Scott et al. 2001, Bragulla et al. 2004, Hargis \& Ginn 2007).

\section{Elementos celulares dérmicos}

As células predominantes na derme são os fibroblastos (Kristensen 1975, Headington \& Cerio 1990), os macrófagos e os mastócitos (Kristensen 1975, Scott 1980). Outras células esparsamente presentes incluem linfócitos e plasmócitos, que, junto com as células de Langerhans, formam o tecido linfóide associado à pele (Hargis \& Ginn 2007). Em algumas regiões do corpo, a derme profunda da pele com pêlos possui variável quantidade de adipócitos (Monteiro-Riviere et al. 1993).

Os mastócitos da pele são vistos principalmente ao redor dos vasos sangüíneos, especialmente ao redor de vênulas pós-capilares (Affolter \& Moore 1994, Ginn et al. 2007), e sua quantidade é variável (Yager \& Scott 1993, Yager \& Wilcock 1994), principalmente em relação à localização e à espécie animal (Yager \& Scott 1993). No entanto, no passado se acreditava que não havia variação regional no número de mastócitos e que um número inferior a 12 por campo de grande aumento (CGA) estava dentro do normal (Kristensen 1975). Segundo alguns autores (Yager \& Wilcock 1994, Scott et al. 2001), cães e gatos apresentam 4-12 e 4-20 mastócitos por CGA na pele, respectivamente. Entretanto, encontra-se na literatura limites acima de 20 mastócitos/CGA para gatos (Affolter \& Moore 1994, Yager \& Scott 1993). Embora esses valores sejam usualmente utilizados por patologistas para considerar o aumento na quantidade de mastócitos dérmicos, o parâmetro fisiológico de mastócitos por CGA é muito variável (Yager \& Wilcock 1994), ao ponto de certos autores chegarem a considerar os valores de 0-40 mastócitos/CGA em cães e de 0-60 mastócitos/CGA em gatos como normais (Ginn et al. 2007). Com base nesses aspectos pode-se compreender que é difícil estabelecer um parâmetro quantitativo de referência para os mastócitos dérmicos (Yager \& Wilcock 1994). É interessante que o patologista familiarize-se com a quantidade normal de mastócitos na pele das diferentes regiões do corpo de cães e gatos através da observação de seus casos da rotina, pois esse exercício diário parece ser mais útil para se saber quando há mais mastócitos do que o simples emprego de limites com distribuição tão ampla.

Os grânulos dos mastócitos não se coram na colora- 
ção de HE e, assim, não são tão facilmente identificados como quando se utilizam colorações metacromáticas, como o azul de Toluidina (Yager \& Scott 1993, Yager \& Wilcock 1994, Scott et al. 2001, Ginn et al. 2007); entretanto, embora tais colorações especiais sejam úteis, elas não são essenciais na identificação de mastócitos dérmicos não-neoplásicos (Yager \& Wilcock 1994).

\section{Fibras dérmicas}

As fibras dérmicas são produzidas pelos fibroblastos e podem ser colágenas ou elásticas (Bacha \& Wood 1990). As fibras colágenas perfazem de $75 \%$ a $90 \%$ do total, enquanto as fibras elásticas, representadas principalmente pela elastina, correspondem a apenas uma pequena parte das fibras dérmicas. Portanto, a espessura da derme da pele com pêlos está correlacionada com a quantidade e com o diâmetro dos feixes de colágeno (Meyer \& Neurand 1987).

Dentre as fibras colágenas destacam-se as do tipo I (87\%), III (10\%) e V (3\%). No cão e no gato, a derme superficial é formada principalmente por fibras colágenas finas, frouxamente arranjadas e distribuídas de forma irregular, já a derme profunda contém principalmente fibras colágenas espessas, densamente organizadas e distribuídas paralelamente à superfície cutânea (Affolter \& Moore 1994, Scott et al. 2001).

\section{Vasos sangüíneos e linfáticos}

Existem três plexos intercomunicantes de artérias e veias na pele dos cães e gatos (Banks 1992, MonteiroRiviere et al. 1993, Scott et al. 2001, Bragulla et al. 2004, Hargis \& Ginn 2007): plexo venoso profundo da derme, localizado na interface da derme com o tecido subcutâneo; plexo venoso subpapilar profundo, localizado entre a derme superficial e profunda; e plexo venoso subpapilar superficial, localizado entre a derme superficial e a epiderme (Bragulla et al. 2004). Além das células endoteliais, os capilares cutâneos são compostos por perícitos e células do véu (Scott et al. 2001). Os perícitos são células fusiformes contráteis alinhadas paralelamente ao vaso, importantes na regulação do fluxo capilar (Bal 1996). As células do véu, que são similares a fibroblastos, circundam os vasos externamente à lâmina basal (Scott et al. 2001).

Os vasos linfáticos da pele drenam para o plexo linfático subcutâneo (Affolter \& Moore 1994, Scott et al. 2001, Bragulla et al. 2004, Hargis \& Ginn 2007) e diferenciamse dos vasos sangüíneos por terem a luz mais ampla e angular, possuírem células endoteliais achatadas e mais delgadas e não conterem sangue (Gross et al. 2005).

\section{Tecido nervoso}

$\mathrm{Na}$ derme observam-se nervos autônomos e sensoriais (Bragulla et al. 2004). Os nervos autônomos formam plexos perivasculares constituídos apenas por fibras simpáticas que inervam os vasos sangüíneos (Roberts \& Levitt 1982), as glândulas (Sokolov et al. 1980, Sokolov et al. 1981) e os músculos eretores do pêlo (Roberts \& Levitt
1982). As fibras nervosas sensoriais formam o plexo nervoso subcutâneo da derme, que mantém relação com o plexo nervoso subcutâneo do tecido subcutâneo (Bragulla et al. 2004). O plexo nervoso subcutâneo da derme se continua na forma de terminações nervosas sensoriais para pressão, tato, temperatura e dor. Essas terminações nervosas mantêm íntima relação com os folículos pilosos, mas, principalmente, com os folículos tilotríquios e os folículos sinusais (Halata 1993).

\section{Tecido muscular}

Os músculos eretores do pêlo são músculos lisos que se originam na derme superficial e se inserem na bainha de tecido conjuntivo fibroso do folículo piloso primário (Webb \& Calhoun 1954). Esses músculos são ancorados por fibras elásticas em suas inserções (Monteiro-Riviere et al. 1993) e respondem à liberação de epinefrina e norepinefrina, contraindo-se, causando piloereção e esvaziamento das glândulas sebáceas (Banks 1992, Monteiro-Riviere et al. 1993, Affolter \& Moore 1994, Scott et al. 2001). Feixes de músculo esquelético são observados apenas na derme da face e do escroto (Dunstan 2002); entretanto, algumas dessas fibras podem estar presentes em associação com os folículos pilosos táteis de outras áreas da pele (Affolter \& Moore 1994).

Acredita-se que a função principal do músculo eretor do pêlo seja contribuir para os mecanismos de defesa dos carnívoros, já que ao elevarem o pêlo tornam o indivíduo maior frente ao seu oponente (Klemm 1996). Além disso, sabe-se que esse mecanismo auxilia na termoregulação (Monteiro-Riviere et al. 1993, Scott et al. 2001). Esses músculos estão distribuídos por toda a pele com pêlos e são mais desenvolvidos na linha média dorsal (Yager \& Wilcock 1994, Dunstan 2002), principalmente no pescoço (Monteiro-Riviere et al. 1993), e ao longo de todo o dorso, incluindo a cauda (Kristensen 1975). Alguns autores citam que os músculos eretores do pêlo do escroto são maiores do que os observados em outros locais do corpo (Dunstan 2002). A presença de vacúolos intracelulares e extracelulares no músculo eretor do pêlo é um achado normal e a quantidade desses vacúolos aumenta com a idade (Yager \& Scott 1993).

\section{FOLÍCULOS PILOSOS}

Cães e gatos possuem folículos pilosos compostos, formados por vários folículos pilosos primários e secundários (Affolter \& Moore 1994). Pêlos primários emergem em poros separados, ao contrário dos pêlos secundários, que emergem em poros comuns. Em média, há de 5 a 20 pêlos secundários para cada pêlo primário em cães e gatos (Affolter \& Moore 1994, Scott et al. 2001). Esses pêlos secundários rodeiam os primários (Bragulla et al. 2004). Alguns folículos pilosos compostos possuem dois a cinco pêlos primários com um grande pêlo primário central (Affolter \& Moore 1994).

Em carnívoros, excetuando-se seus filhotes, há sempre múltiplas hastes foliculares na altura do infundíbulo. 
Isso difere dos folículos pilosos da maioria dos herbívoros e onívoros, nos quais há apenas uma haste folicular no interior do infundíbulo (Dunstan 2002). Os folículos primários possuem uma glândula sudorípara apócrina, uma glândula sebácea e um músculo eretor do pêlo; os folículos secundários podem possuir apenas glândula sebácea (Monteiro-Riviere et al. 1993, Affolter \& Moore 1994).

Embora os folículos pilosos estejam distribuídos por quase toda a pele, menos nos coxins e no plano nasal (Yager \& Wilcock 1994), a quantidade e o tamanho desses folículos são muito variáveis. Folículos pilosos maiores, por exemplo, são vistos na face e na extremidade distal dos membros (Dunstan 2002).

\section{Regiões anatômicas do folículo piloso}

Os folículos pilosos são divididos longitudinalmente em três segmentos anatômicos: o infundíbulo ou porção pilossebácea, o istmo e o segmento inferior (Scott et al. 2001). O primeiro localiza-se da abertura do ducto sebáceo até o óstio folicular, o segundo se estende da inserção do músculo eretor do pêlo até a abertura do ducto sebáceo e o último localiza-se desde a papila dérmica do pêlo até a inserção do músculo eretor do pêlo (Fig.5) (Scott et al. 2001, Gross et al. 2005). O infundíbulo é constituído por um estrato idêntico à epiderme, já o epitélio do istmo folicular é

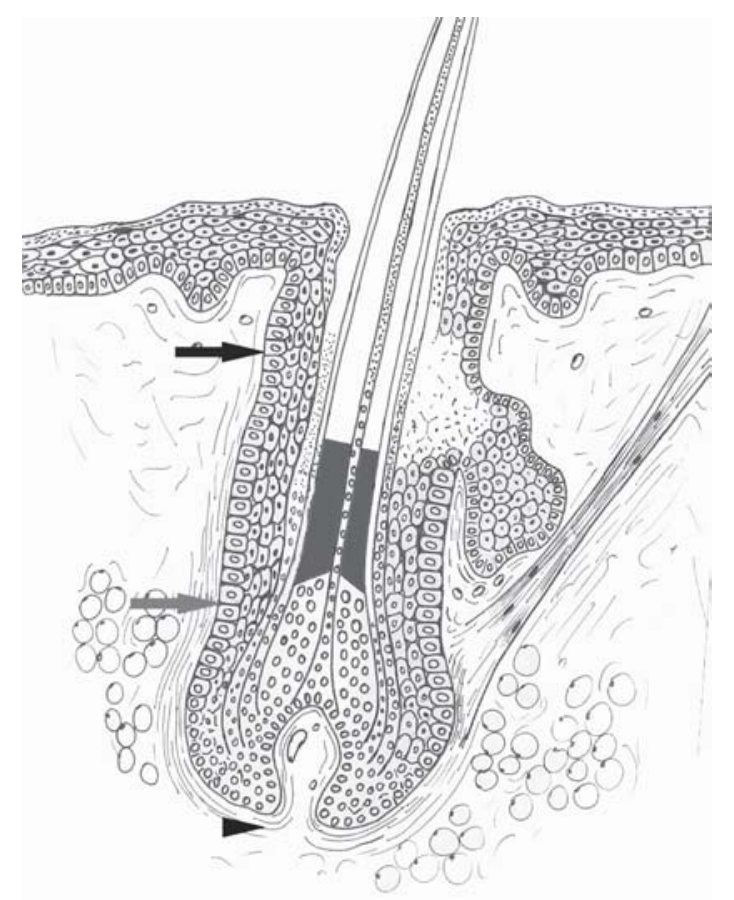

Fig.5. Pele com pêlos (Cão). Representação esquemática de um corte longitudinal de um folículo piloso demonstrando suas diferentes regiões anatômicas. O infundíbulo compreende a porção acima da abertura do ducto da glândula sebácea (porção acima da seta preta). O istmo corresponde à porção entre o ducto de abertura da glândula sebácea e a inserção do músculo eretor do pêlo (porção entre as setas preta e cinza). O segmento inferior se estende da papila dérmica do pêlo até a inserção do músculo eretor do pêlo (porção entre a seta cinza e a cabeça de seta). composto por ceratinócitos menores e que se ceratinizam sem demonstrar o estrato granular (Gross et al. 2005). O epitélio folicular desses dois segmentos é denominado bainha radicular externa (bainha externa da raiz ou bainha folicular externa). O segmento inferior contém, além da bainha radicular externa, um agrupamento de células basalóides (células da matriz), denominado matriz germinativa, que dá origem a bainha radicular interna e ao pêlo (Scott et al. 2001, Gross et al. 2005). Na base do folículo

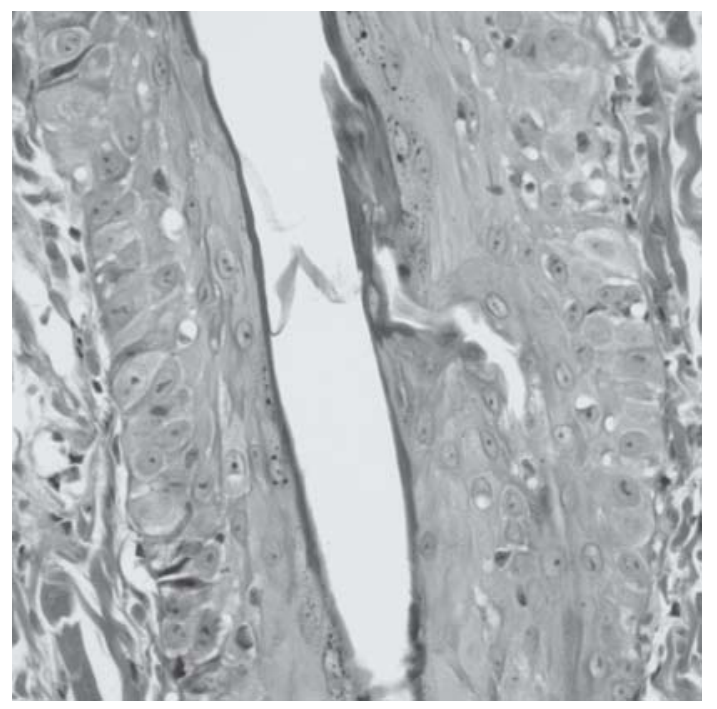

Fig.6. Pele com pêlos (Cão). Folículo piloso, infundíbulo (corte longitudinal). Essa região do folículo piloso é constituída pelos mesmos estratos da epiderme. HE, obj.20x.

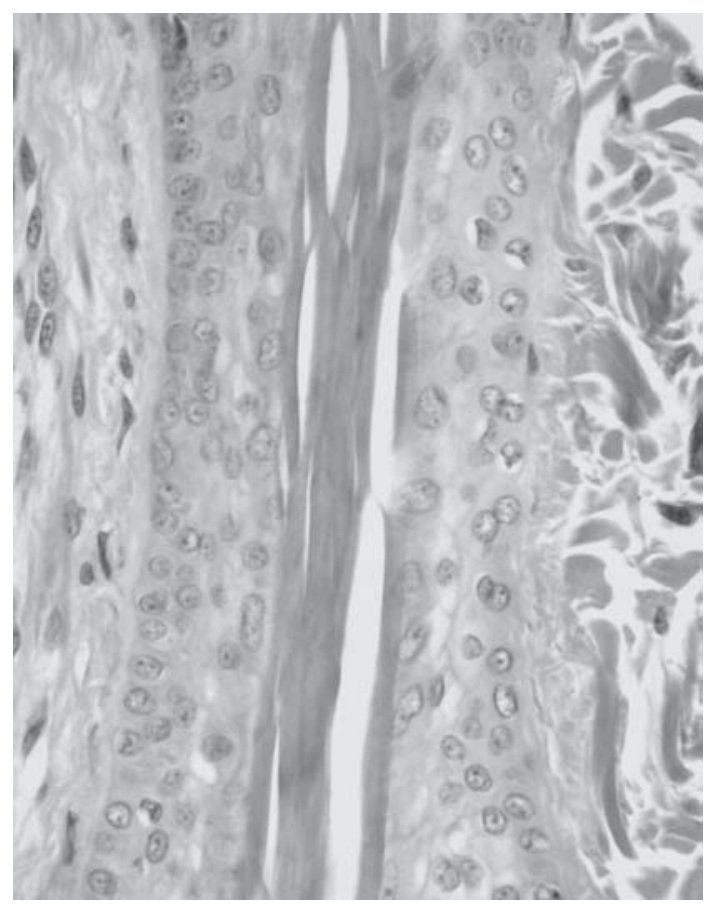

Fig.7. Pele com pêlos (Cão). Folículo piloso, istmo (corte longitudinal). Essa região do folículo piloso é constituída por ceratinócitos que não formam estrato granuloso. HE, obj.20x. 
piloso, essa matriz germinativa é contínua com a bainha radicular externa. Por apresentar um formato diferente do restante do folículo piloso, a porção distendida do segmento inferior recebe o nome de bulbo folicular, bulbo do pêlo ou bulbo piloso (Kierszenbaum 2006).

Embora o folículo piloso esteja localizado na derme, ele está separado dessa pela membrana basal (Bacha \& Wood 1990), ou seja, a bainha radicular externa é contínua com o estrato basal, espinhoso e granuloso da epiderme (Banks 1992). Assim, no infundíbulo, todos os estratos da epiderme estão presentes (Fig.6), entretanto, no istmo, a bainha radicular externa diferencia-se por não mais possuir o estrato granuloso (Fig.7) (Scott et al. 2001). As células que constituem a bainha radicular externa do segmento inferior têm citoplasma acentuadamente vacuolizado (Fig.8). Em seções coradas pelo PAS, o citoplasma dessas células se mostra rico em grânulos de glicogênio (Monteiro-Riviere et al. 1993). Com base nessas características estruturais, a bainha radicular externa tem espessura variável de acordo com sua localização em cada segmento anatômico do folículo piloso, ou seja, é mais grossa no infundíbulo e mais fina no segmento inferior (Scott et al. 2001). Externamente, toda a bainha radicular externa é circundada por uma bainha de tecido conjuntivo fibroso denominada bainha radicular fibrosa (Monteiro-Riviere et al. 1993) ou membrana hialóidea (Grau \& Walter 1975).

O bulbo do pêlo está situado sobre uma papila de tecido conjuntivo dérmico (papila dérmica do pêlo) (Fig.9), mas separado dessa por uma fina lâmina basal (membrana vítrea) que se continua com a membrana basal epidérmica (Banks 1992). Essa papila tem como principal função nutrir o segmento inferior do folículo piloso e desempenha um papel fundamental na proliferação e diferenciação epiteliais (Kristensen 1975). As células mesenquimais que constituem a papila dérmica do pêlo são consideradas o principal alvo na resposta a hormônios que têm ação sobre o folículo piloso (Banks 1992, Scott et al. 2001). O tamanho, o formato e a quantidade de matriz extracelular no interior da papila dérmica do pêlo são variáveis de acordo com a fase do ciclo de crescimento do pêlo (Banks 1992, Monteiro-Riviere et al. 1993, Scott et al. 2001).

A bainha radicular interna (bainha interna da raiz ou bainha folicular interna) está encerrada entre a bainha radicular externa e o pêlo, origina-se a partir do bulbo piloso e é subdividida em três regiões: camada de Henle ou periférica, camada de Huxley ou intermediária e cutícula da bainha radicular interna (Kristensen 1975, Banks 1992, Monteiro-Riviere et al. 1993, Scott et al. 2001). A principal função da bainha radicular interna é servir como um molde para a formação do pêlo. A camada de Henle consiste em apenas uma camada de células achatadas e anucleadas (Banks 1992). A camada de Huxley possui uma a três camadas de células com grânulos eosinofílicos conspícuos, os grânulos de tricohialina (Monteiro-Riviere et al. 1993), que são os grânulos de cerato-hialina do pêlo (Banks 1992). A cutícula da

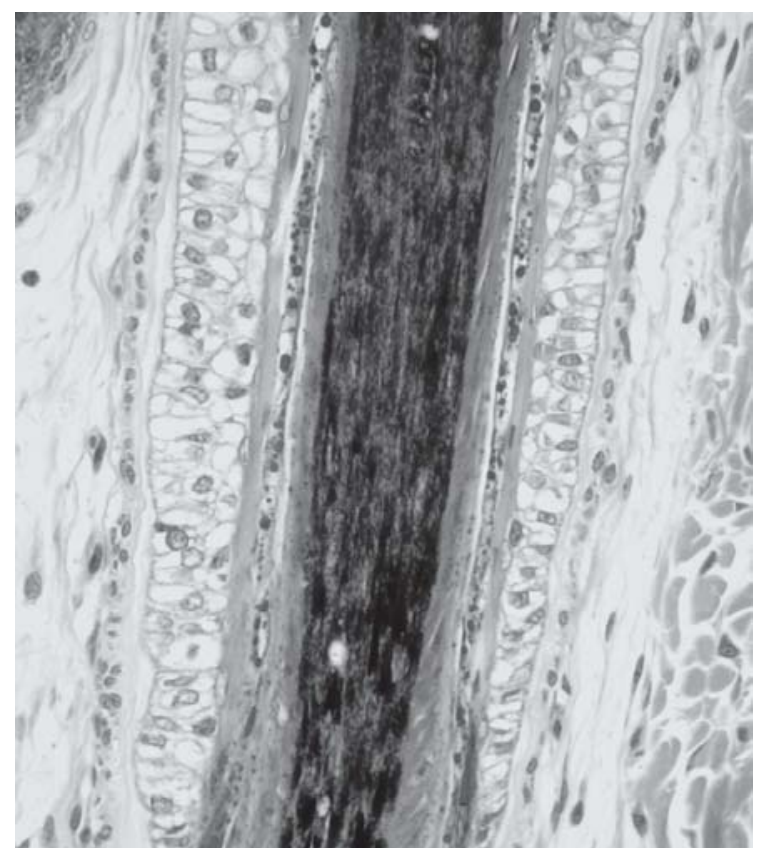

Fig.8. Pele com pêlos (Cão). Folículo piloso, segmento inferior (corte longitudinal). Nessa região do folículo piloso, a bainha radicular externa é formada por células com citoplasma acentuadamente vacuolizado. Observe também os grânulos eosinofílicos (grânulos de trico-hialina) na camada de Huxley da bainha radicular interna. HE, obj.20x.

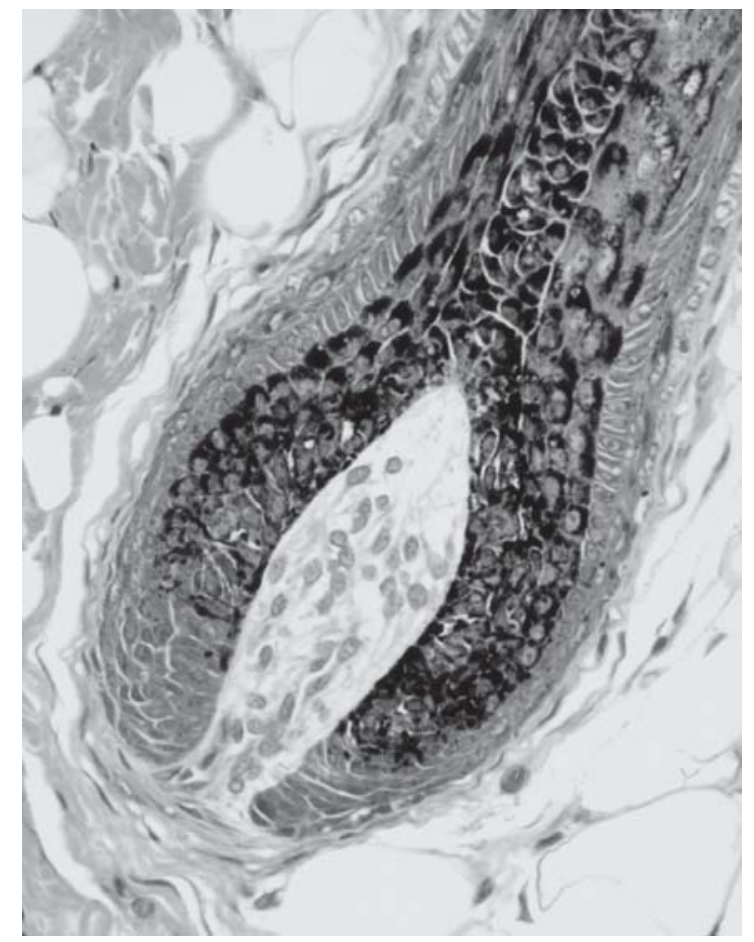

Fig.9. Pele com pêlos (Cão). Folículo piloso, bulbo piloso (corte longitudinal). Um aglomerado de células epiteliais dá à base do folículo piloso um típico aspecto dilatado. Observe o acúmulo de células mesenquimais imerso na matriz extracelular e parcialmente encerrado pelas paredes do bulbo piloso (papila dérmica). HE, obj.20x. 
bainha radicular interna é uma monocamada de células ceratinizadas que se apóia sobre a cutícula do pêlo (Scott et al. 2001). As três camadas que formam a bainha radicular interna não são contínuas com a superfície, pois não se estendem além da inserção do músculo eretor do pêlo nos folículos pilosos. Assim, no istmo, as camadas da bainha radicular interna passam a não mais serem definidas, pois as células que as constituem sofrem ceratinização (Banks 1992).

A ceratina sintetizada pelas células epiteliais das três porções do folículo piloso é distinta; os ceratinócitos infundibulares formam ceratina lamelar (ceratinização lamelar) e os pequenos ceratinócitos da região do istmo sintetizam ceratina amorfa (ceratinização tricolemal ou triquilêmica) (Scott et al. 2001, Gross et al. 2005). A ceratina formada pelas células da matriz (ceratinização matrical) é responsável por sua transformação, que inclui um aumento da eosinofilia citoplasmática e a dissolução gradual do núcleo, sem destruição da membrana citoplasmática e nuclear (Gross et al. 2005). Após esse processo forma-se uma célula apoptótica com constituintes pouco discerníveis na microscopia de luz e conhecida como "célula-fantasma" (Scott et al. 2001). O reconhecimento das diferenças nesse processo de ceratinização é fundamental para a classificação correta dos cistos foliculares e de certos neoplasmas que emergem das células produtoras de ceratina (Souza 2005).

\section{Pêlos}

Os pêlos possuem três regiões distintas, a cutícula, o córtex e a medula (Bacha \& Wood 1990, Banks 1992, Monteiro-Riviere et al. 1993). A cutícula é uma monocamada de células ceratinizadas e anucleadas que se interdigitaliza com a cutícula da bainha radicular interna (Scott et al. 2001). O córtex é formado por várias camadas de células fusiformes e ceratinizadas que contêm ceratina dura (Banks 1992, Scott et al. 2001). A medula é formada por fileiras de células cubóides ou células achatadas (Monteiro-Riviere

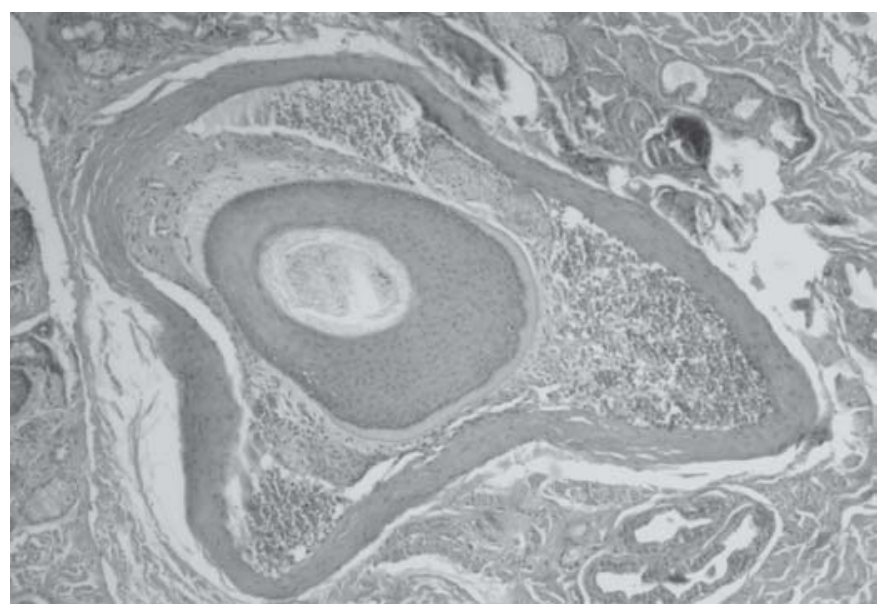

Fig.10. Pele com pêlos (Cão). Folículo sinusal (corte transversal). Observe o amplo seio venoso que separa a membrna vítrea da bainha radicular fibrosa. $\mathrm{HE}$, obj.4x. et al. 1993), que, de acordo com a região, podem estar separadas por variável quantidade de ar (Kristensen 1975). Em certas espécies de mamíferos, mas não em cães e gatos, alguns pêlos podem não possuir medula (pêlos lanugos) (Monteiro-Riviere et al. 1993).

A medula dos pêlos secundários é mais estreita que a dos pêlos primários e sua cutícula é mais saliente. A cor do pêlo é dada principalmente pela quantidade e distribuição dos diferentes tipos de melanina no córtex (Affolter \& Moore 1994, Scott et al. 2001). A deposição do pigmento pode ser uniforme por todas as partes da haste do pêlo ou pode variar por todo o comprimento de um único pêlo, como ocorre, por exemplo, no Pastor Alemão (Affolter \& Moore 1994).

\section{Pêlos especializados}

São encontrados dois tipos especializados de pêlos táteis na pele dos mamíferos, os pêlos sinusais e os pêlos tilotríquios (Kristensen 1975, Affolter \& Moore 1994); ambos servem como típicos órgãos de toque (Halata 1993). Os folículos sinusais, dos quais emergem os pêlos sinusais, são encontrados no focinho, nos lábios, nas pálpebras e na região cárpica (Affolter \& Moore 1994), nessa última região, os pêlos sinusais são vistos como pequenos tufos de cinco ou seis pêlos rígidos (Kristensen 1975). Os folículos sinusais estão embebidos em um seio anular, preenchido por sangue venoso, entre a membrana vítrea e a bainha radicular fibrosa (Fig.10) (Kristensen 1975, Bacha \& Wood 1990, Monteiro-Riviere et al. 1993, Bal 1996, Scott et al. 2001, Hargis \& Ginn 2007), mantém íntima relação com o coxim sinusal (Bacha \& Wood 1990, Monteiro-Riviere et al. 1993) e possuem aproximadamente 2.000 terminações nervosas sensoriais que incluem terminações nervosas livres, terminações nervosas lanceoladas, terminações nervosas de Merkel, corpúsculos de Ruffini e corpúsculos lamelares de Vater-Pacini (Halata 1993).

Os pêlos tilotríquios estão espalhados pelo corpo, entre as unidades de folículo piloso (Kristensen 1975), e seus folículos são bem maiores do que os folículos pilosos nãoespecializados que os circundam. Os pêlos tilotríquios são considerados mecanorreceptores de adaptação rápida. Folículos tilotríquios são vistos nas regiões em que a epiderme é espessa e está sustentada por tecido conjuntivo bastante inervado e vascularizado, ou seja, ocorrem em íntima associação com coxins tilotríquios, um dos órgãos de toque mais importantes da pele dos mamíferos (Kristensen 1975, Affolter \& Moore 1994). Além disso, folículos tilotríquios estão circundados por um tecido neurovascular ao nível do istmo (Hargis \& Ginn 2007), mais precisamente ao nível da glândula sebácea (Kristensen 1975) e as fibras nervosas que rodeiam esses folículos interagem com as células de Merkel (Banks 1992).

\section{GLÂNDULAS SEBÁCEAS}

As glândulas sebáceas são glândulas alveolares, simples e holócrinas (Kristensen 1975). O termo holócrino denota o tipo de secreção glandular no qual toda a célula 
secretora, junto com os produtos secretórios acumulados, forma o material secretado (Dorland 1999). As glândulas sebáceas estão distribuídas por toda a pele com pêlos (Webb \& Calhoum 1954), mas são maiores e mais numerosas nas junções mucocutâneas, nos espaços interdigitais, na face dorsal do pescoço, na região mentoniana, na região lombossacra e na face dorsal da cauda (Affolter \& Moore 1994, Scott et al. 2001). Segundo outros autores, as glândulas sebáceas são mais abundantes na face e essa característica é mais evidente em gatos do que em cães (Dunstan 2002).

Na pele com pêlos, as glândulas sebáceas descarregam seu conteúdo em um ducto para dentro do folículo piloso (Neilsen 1953), na região no istmo (Affolter \& Moore 1994). Na pele sem pêlos, como nas junções mucocutâneas (por exemplo, na margem labial e no ânus), na pálpebra e no canal auditivo externo, os ductos sebáceos se abrem diretamente na superfície da pele (Affolter \& Moore 1994). Os coxins de cães e gatos, semelhante à palma das mãos e à sola dos pés em humanos, e o plano nasal não possuem glândulas sebáceas (Affolter \& Moore 1994).

Os lóbulos sebáceos são constituídos por um grupo de alvéolos sebáceos contornados pela membrana basal e por uma única camada de células basais, denominadas células-reserva (Gross et al. 2005), células-fonte (Banks 1992), células basais (Bacha \& Wood 1990) ou células da matriz (Kühnel 2005). Essas células periféricas são precursoras dos sebócitos maduros, que amadurecem e morrem por apoptose à medida que migram da periferia da glândula em direção ao ducto excretor, um processo denominado holocitose (Kühnel 2005). Nessa jornada os sebócitos acumulam lipídios em seu citoplasma (Fig.11) (Bacha e Wood 1990, Banks 1992, Monteiro-Riviere et al. 1993). Os sebócitos dos gatos diferem dos sebócitos dos cães principalmente no que se refere ao tamanho, que nessa espécie é bastante variável (Dunstan 2002). O ducto excretor das glândulas sebáceas é revestido por epitélio estratificado pavimentoso (Monteiro-Riviere et al. 1993).

\section{GLÂNDULAS SUDORÍPARAS}

As glândulas sudoríparas, tanto nos cães quanto nos gatos, desempenham uma importante função na integridade da pele, mas não são importantes na termorregulação (Affolter \& Moore 1994). Existem dois tipos de glândulas sudoríparas, as apócrinas, epitriquiais ou paratriquiais e as écrinas, merócrinas ou atriquiais (Neilsen 1953). O termo apócrino denota o tipo de secreção glandular no qual a porção apical da célula secretora é desprendida junto com os produtos secretórios acumulados dentro dela; 0 termo merócrino denota o tipo de secreção glandular em que a célula secretora permanece intacta durante todo 0 processo de formação e descarga dos produtos secretórios (Dorland 1999). As chamadas glândulas sudoríparas apócrinas possuem, na verdade, mecanismo de ação do tipo merócrino (Bacha \& Wood 1990, Monteiro-Riviere et al. 1993, Kierszenbaum 2006), entretanto, tal nomenclatura atingiu o status de aceitação devi-

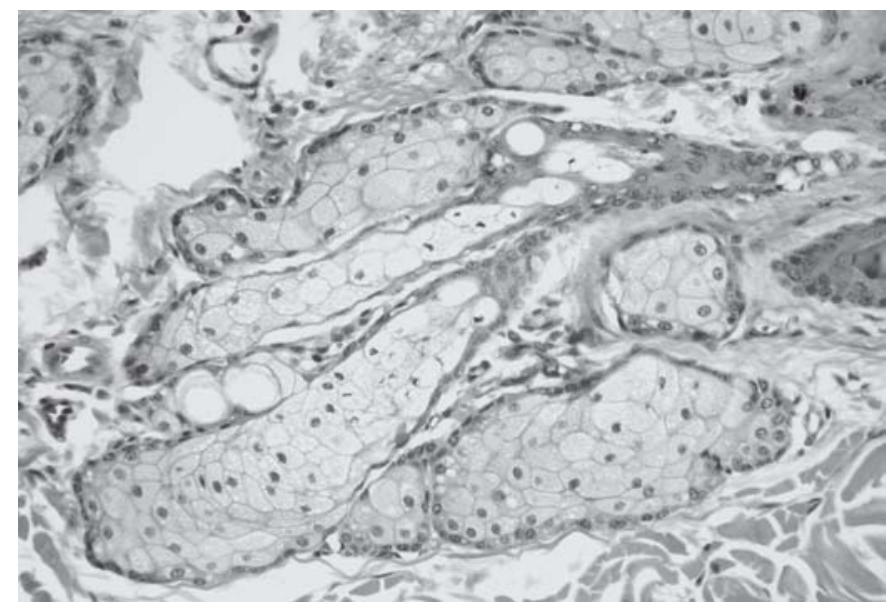

Fig.11. Pele com pêlos (Cão). Glândulas sebáceas. Observe o lóbulo sebáceo revestido por uma única camada de células basalóides (células-reserva). Os sebócitos centrais têm núcleo picnótico e citoplasma distendido devido ao acúmulo de lipídios. HE, obj.20x.

do ao uso comum, tanto em medicina veterinária (Monteiro-Riviere et al. 1993), como em medicina humana (Kierszenbaum 2006). Como o próprio nome sugere as glândulas epitriquiais distribuem-se por toda a pele com pêlos, já as glândulas atriquiais ocorrem apenas em regiões em que não há pêlos, como nos coxins e no plano nasal de cães e gatos (Yager \& Wilcock 1994).

As glândulas apócrinas são glândulas tubulosas, enoveladas e simples, que se localizam abaixo das glândulas sebáceas e abrem-se para dentro do folículo piloso, acima da abertura do ducto sebáceo (Bacha \& Wood 1990, Banks 1992, Monteiro-Riviere et al. 1993). Elas são maiores e mais numerosas próximo às junções mucocutâneas, nos espaços interdigitais e na superfície dorsal do pescoço (Scott et al. 2001). Essas glândulas consistem de uma única fileira de células epiteliais cilíndricas circundadas por uma camada de células mioepiteliais fusiformes (Jenkinson 1971). Freqüentemente observamse saliências citoplasmáticas a partir desse epitélio; tais saliências projetam-se em direção ao lúmen da glândula e desprendem-se num processo denominado decapitação apócrina, extrusão apócrina ou apocitose (Fig.12) (Kühnel 2005). O ducto excretor das glândulas sudoríparas apócrinas possui uma ou duas camadas de células cubóides (Iwasaki 1983).

As glândulas écrinas de cães e gatos são pequenas e localizadas na derme profunda dos coxins (Banks 1992, Scott et al. 2001). Elas são constituídas de uma única camada de células epiteliais cubóides ou cilíndricas (Fig.13) e também são circundadas por uma camada de células mioepiteliais fusiformes (Scott et al. 2001). Essas glândulas são formadas por dois tipos de células secretoras (células claras e células escuras), cada uma delas responsáveis pela secreção de diferentes constituintes (Montagna 1967, Monteiro-Riviere et al. 1993). Seu ducto excretor tem formato de saca-rolhas (Montagna 1967, Dunstan 2002), é 


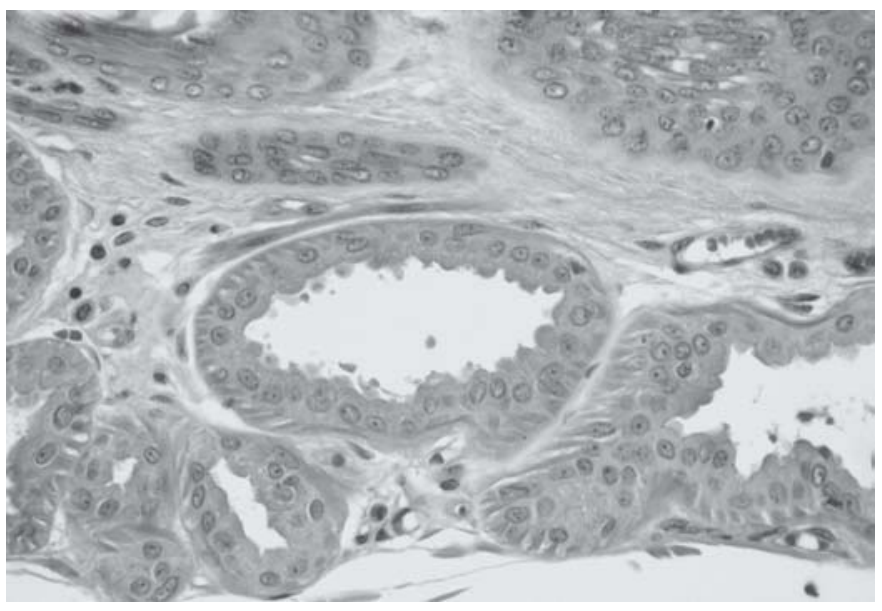

Fig.12. Pele com pêlos (Cão). Glândulas sudoríparas apócrinas. Observe o epitélio simples que compõem a glândula, as pequenas saliências citoplasmáticas projetadas em direção ao lúmen (decaptação apócrina) e o mioepitélio que contorna o ácino. HE, obj.20x.

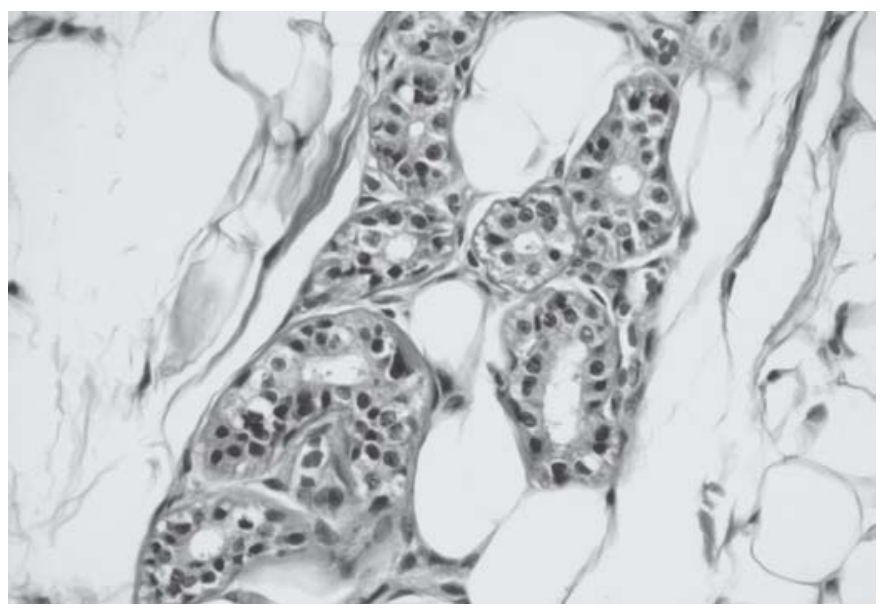

Fig.13. Pele do coxim (Cão). Glândulas sudoríparas écrinas. Um grupo de glândulas écrinas aparece em meio a adipócitos do tecido subcutâneo. As glândulas são pequenas e revestidas por epitélio simples. HE, obj.20x.

composto de uma dupla camada de células epiteliais cubóides e abre-se diretamente na superfície da epiderme (Monteiro-Riviere et al. 1993, Bal 1996).

\section{GLÂNDULAS ESPECIALIZADAS DA PELE}

As glândulas especializadas da pele de cães e gatos são originárias das glândulas sudoríparas apócrinas ou das glândulas sebáceas (Grau \& Walter 1975). Histologicamente, algumas dessas glândulas modificadas são muito semelhantes às suas glândulas de origem, diferindo, em alguns casos, apenas ultra-estruturalmente ou pelo produto de sua secreção (Banks 1992). No cão, as glândulas especializadas incluem: glândulas perianais, glândulas dos sacos anais, glândulas ceruminosas, glândulas de Meibom e glândulas da cauda (Banks 1992, Scott et al. 2001). Com exceção das glândulas perianais, todas as outras também são descritas em gatos (Gross et al. 2005). Além disso, gatos, mas não cães, possuem um acúmulo de glândulas sebáceas modificadas na região mentoniana (órgão submentoniano) (Banks 1992) e ao redor da fenda bucal (glândulas circum-orais) (Grau \& Walter 1975, Bragulla et al. 2004).

\section{Glândulas perianais}

As glândulas perianais (glândulas circum-anais ou glândulas hepatóides) são glândulas sebáceas modificadas encontradas apenas em canídeos e bovídeos (Shabadash \& Zelikina 2002). Essas glândulas estão localizadas principalmente ao redor do ânus (Banks 1992, Monteiro-Riviere et al. 1993). A denominação glândula hepatóide advém do fato de as células sebáceas modificadas presentes nessa glândula serem morfologicamente muito semelhantes aos hepatócitos (Fig. 14) (Grau \& Walter 1975, Isitor \& Weinman 1979, Banks 1992, Monteiro-Riviere et al. 1993, Hargis \& Ginn 2007). Embora a localização circum-anal seja a mais prevalente no cão, as glândulas perianais também ocorrem na base da

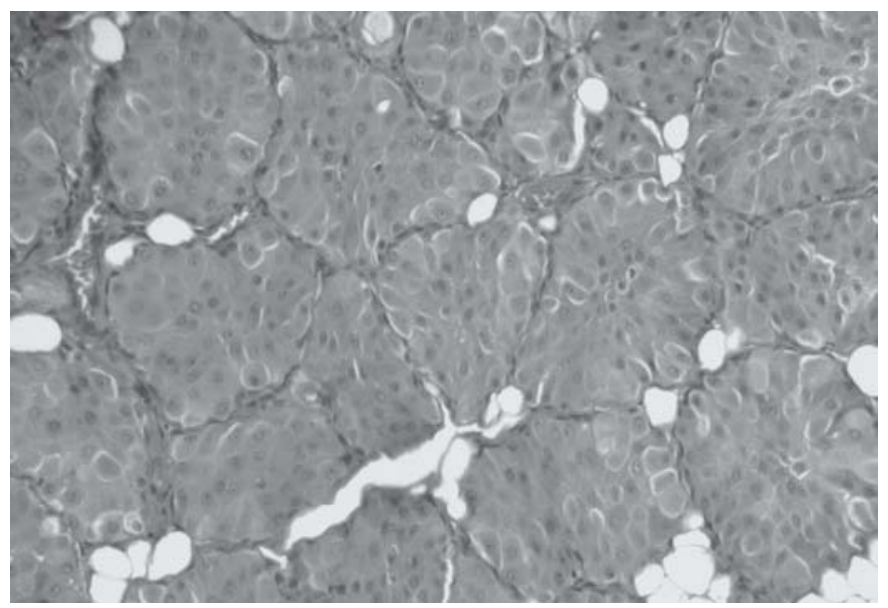

Fig.14. Pele com pêlos (Cão). Glândulas hepatóides. Vários lóbulos de glândulas hepatóides aparecem separados por finos septos de tecido conjuntivo. As células são poligonais com citoplasma eosinofílico e abundante, semelhantes a hepatócitos. HE, obj.20x.

cauda, no flanco, no prepúcio, nas coxas, na região lombossacra dorsal, no tórax e na virilha (Burrows et al. 1992, Monteiro-Riviere et al. 1993, Wilkinson \& Harvey 1996, Jones et al. 2000, Hargis \& Ginn 2007). Ocasionalmente, essas glândulas podem ser encontradas em outras localizações, como na cabeça e nas patas (Gross et al. 2005). Cabe ressaltar que ao redor do ânus do cão e em íntima associação com as glândulas perianais há um menor número de glândulas sudoríparas apócrinas isoladas e pequenos aglomerados de glândulas sebáceas (Isitor \& Weinman 1979, Shabadash \& Zelikina 2002). Alguns autores afirmam que essas glândulas sudoríparas apócrinas servem de ductos excretores para as glândulas perianais (Atoji et al. 1998a, Atoji et al. 1998b). 


\section{Glândulas dos sacos anais}

Os sacos anais (seios perianais ou seios paranais) são invaginações cutâneas localizadas bilateralmente à porção final do reto (Banks 1992, Bragulla et al. 2004), entre os esfíncteres interno e externo do ânus (Hargis \& Ginn 2007). Esses divertículos são vistos em carnívoros e em muitos roedores (Banks 1992). Os sacos anais são revestidos por epitélio estratificado, pavimentoso e ceratinizado (Monteiro-Riviere et al. 1993) e possuem glândulas que se abrem em seu interior, denominadas glândulas dos sacos anais (Bragulla et al. 2004). Nos cães, essas glândulas são sudoríparas apócrinas (Banks 1992, Monteiro-Riviere et al. 1993, Hargis \& Ginn 2007) e nos gatos sudoríparas apócrinas e sebáceas (Sokolov \& Shabadash 1979). Esses sacos possuem um ducto excretor em cada lado do ânus (Banks 1992, MonteiroRiviere et al. 1993). O produto de secreção dessas glândulas em conjunto com células descamadas fica armazenado dentro dos sacos e é liberado durante a defecação ou voluntariamente através da contração do músculo esfíncter externo do ânus (Bragulla et al. 2004).

\section{Glândulas ceruminosas}

As glândulas ceruminosas (glândulas do conduto auditivo externo) são glândulas sudoríparas apócrinas modificadas que ocorrem em toda a extensão do conduto auditivo e são responsáveis pela produção do cerúmen (Monteiro-Riviere et al. 1993, Hargis \& Ginn 2007).

\section{Glândulas de Meibom}

As glândulas de Meibom (glândulas tarsais) são glândulas sebáceas modificadas localizadas na superfície interna das pálpebras (Banks 1992), principalmente na pálpebra superior (Monteiro-Riviere et al. 1993). Essas glândulas são holócrinas e produzem uma secreção viscosa e oleosa que é transportada por um ducto para a margem da pálpebra (Banks 1992). Histologicamente, as glândulas de Meibom são idênticas às glândulas sebáceas localizadas em outras regiões da pele (Banks 1992).

\section{Glândulas da cauda}

A glândula da cauda (glândula supra-caudal ou glândula uropígia) é uma glândula especializada presente na face dorsal da cauda do cão e do gato (Banks 1992, Bragulla et al. 2004). No cão, essa glândula é pequena, bem circunscrita e ocorre apenas na base da cauda, entre a quinta e a sétima vértebras coccígeas, aproximadamente $2,5-5,0 \mathrm{~cm}$ distais ao ânus (Banks 1992) ou 3,0-9,0cm a partir da base da cauda (Monteiro-Riviere et al. 1993). No gato, a glândula da cauda estende-se por toda a superfície dorsal da cauda e é denominada de órgão supra-caudal ou órgão dorsal da cauda (Strickland \& Calhoun 1963). No cão, a glândula da cauda é uma glândula hepatóide (Scott et al. 2001). Embora a maior parte dos autores considere a glândula da cauda do gato como uma glândula sebácea (Strickland \& Calhoun 1963, Scott 1980), evidências indicam que ela possui todas as características morfológicas necessárias para ser considerada também como uma glândula hepatóide (Shabadash \& Zelikina 1997).

\section{Órgão submentoniano e glândulas circum-orais}

O órgão submentoniano dos gatos está localizado no espaço intermandibular e é formado pelo acúmulo de glândulas sebáceas modificadas (Monteiro-Riviere et al. 1993, Banks 1992). Além disso, gatos apresentam grande quantidade de glândulas sebáceas ao redor da fenda bucal (glândulas circum-orais) (Bragulla et al. 2004). Essas glândulas sebáceas diferenciam-se principalmente por serem muito grandes (Kristensen 1975).

\section{REFERÊNCIAS}

Atoji Y., Yamamoto Y., Komatsu T., Suzuki Y. \& Tsubota T. 1998a. Circumanal glands of the dog: A new classification and cell degeneration. Anat. Rec. 250:251-267.

Atoji Y., Yamamoto Y. \& Suzuki Y. 1998b. Apocrine sweat glands in the circumanal glands of the dog. Anat. Rec. 252:403-412.

Affolter V.K. \& Moore K. 1994. Histologic features of normal canine and feline skin. Clin. Dermatol. 12:491-497.

Ackerman A.B. 1978. Histologic diagnosis of inflammatory skin diseases. Lea and Febiger, Philadelphia.

Bacha W.J. \& Wood L.M. 1990. Color atlas of veterinary histology. Lea and Febiger, Philadelphia. 269p.

Bal H.S. 1996. Pele, p.560-570. In: Swenson M.J. \& Reece W.O. (Ed.), Dukes' Fisiologia dos Animais Domésticos. 11ํㅡㄹ ed. Guanabara Koogan, Rio de Janeiro. 856p.

Banks W.J. 1992. Histologia Veterinária Aplicada. $2^{\mathfrak{a}}$ ed. Manole, São Paulo. 629p.

Bragulla H., Budras K.D., Mülling C., Reese S. \& König H.E. 2004. Tegumento comum, p.325-380. In: König H.E. \& Liebick H.G. (Ed.), Anatomia dos Animais Domésticos: texto e atlas colorido. Vol.2. Artmed, Porto Alegre. 399p.

Burrows C.F. \& Ellison G.V. 1992. Moléstias anorretais, p.1633-1648. In: Ettinger S.J. (Ed.), Tratado de Medicina Interna Veterinária: moléstias do cão e do gato. Vol.3. 3aㅡ ed. Manole, São Paulo. 1853p.

Dicionário Médico Ilustrado Dorland. 1999. 28a ed. Manole, São Paulo. $2217 p$.

Dustan R.W. 2002. Dermatopathology Symposium. C.L. Davis, Houston. 50p.

Ginn P.E., Mansel J.E.K.L. \& Rakich P.M. 2007. Skin and appendages, p.553-781. In: Maxie M.G. (Ed.), Jubb, Kennedy, and Palmer's Pathology of Domestic Animals. Vol.2. 5th ed. Saunders Elsevier, Philadelphia. 771p.

Grau H. \& Walter P. 1975. Histología y Anatomia Microscópica Comparada de los Mamíferos Domésticos. Labor, Barcelona. 210p.

Gross T.L., Ihrke P.J. \& Walder E.J. 1992. Veterinary Dermatopathology: A macroscopic and microscopic evaluation of canine and feline skin disease. Mosby, St Louis. 520p.

Gross T.L., Ihrke P.J., Walder E.J. \& Affolter V.K. 2005. Skin Diseases of the Dog and Cat: Clinical and histopathologic diagnosis. 2nd ed. Blackwell, Oxford. 932p.

Guaguère E. 1985. Troubles de la pigmentation mélanique des carnivores Ire partie: Élements de physiopathologic. Point Vét. 17:549.

Halata Z. 1993. Sensory inervation of the hairy skin (light-and electronmicroscopic study. J. Invest. Dermatol. 101:75-81.

Hargis A.M. \& Ginn P.E. 2007. The integument, p.1107-1261. In: McGavin M.D. \& Zachary J.F. (Ed.), Pathologic Basis of Veterinary Disease. 4th ed. Mosby Elsevier, St Louis. 1476p.

Headington J.T. \& Cério R. 1990. Dendritic cells and the dermis. Am. J. Dermatopathol. 12:217. 
Isitor G.N. \& Weinman D.E. 1979. Origin and early development of canine circumanal glands. Am. J. Vet. Res. 40:487-492.

Iwasaki T. 1983. Electron microscopy of the canine apocrine sweat duct. Nippon Juigaku Zasshi 45:739-746.

Jenkinson D.M. 1971. Myoepithelial cells of the sweat glands of domestic animals. Res. Vet. Sci. 12:152-155.

Jones T.C., Hunt R.D. \& King N.W. 2000. A pele e seus apêndices, p.831-886. In: Jones T.C., Hunt R.D. \& King N.W. (Ed.), Patologia Veterinária. $6^{\mathrm{a}}$ ed. Manole, São Paulo. 1415p.

Kierszenbaum A.L. 2006. Histology and Cell Biology: An introduction to pathology. $2^{\text {nd }}$ ed. Mosby Elsevier, St Louis. 688p.

Klemm W.R. 1996. Fisiologia comportamental, p.825-841. In: Swenson M.J. \& Reece W.O. (Ed.), Dukes' Fisiologia dos Animais Domésticos. $11^{\mathrm{a}}$ ed. Guanabara Koogan, Rio de Janeiro. 856p.

Kristensen S. 1975. A study of skin diseases in dogs and cats. I. Histology of the hair skin of dogs and cats. Nord. Vet. Med. 27:593-603.

Kühnel W. 2005. Citologia, Histologia e Anatomia Microscópica: texto e atlas. $11^{\underline{a}}$ ed. Artmed, Porto Alegre. 535p.

Lloyd D.H. \& Garthwaite G. 1982. Epidermal structure and surface topography of canine skin. Res. Vet. Sci. 33:99.

Lovell J.E. \& Getty R. 1957. The hair follicle, epidermis, dermis, and skin glands of the dog. Am. J. Vet. Res. 18:873.

McCall C.A. \& Cohen J.J. 1991. Programmed cell death in terminally differentiating keratinocytes. J. Invest. Dermatol. 97:111-114.

McKee P.H. 1999. Essential Skin Pathology. Mosby, London. 250p.

Neilsen S.W. 1953. Glands of the canine skin. Am. J. Vet. 14:448.

Meyer W., Schwarz R. \& Neurand K. 1978. The skin of domestic mammals as model for the human skin, with special reference to the domestic pig. Curr. Probl. Dermatol. 7:32-59.

Meyer W. \& Neurand K. 1987. A comparative scanning electron microscopic view of the integument of domestic mammals. Scanning Microsc. 1:169-180.

Montagna W. 1967. Comparative anatomy and physiology of the skin. Arch. Dermatol. 96:357-363.

Montagna W. 1971. Cutaneous comparative biology. Arch. Dermatol. 104:577.

Monteiro-Riviere N.A., Stinson A.W. \& Calhoun H.L. 1993. Integument, p.285-312. In: Dieter-Dellmann H. (Ed.), Textbook of Veterinary Histology. 4th ed. Lea and Febiger, Philadelphia. 351p.
Polakowska R.H., Piacentini M. \& Bartlett R. 1994. Apoptosis in human skin development: morphogenesis, periderm, and stem cells. Develop. Dynamics 199:176-188.

Roberts W.J. \& Levitt G.R. 1982. Histochemical evidence for sympathetic innervation of hair receptor afferents in cat skin. J. Comp. Neurol. 210:204-209.

Shabadash S.A. \& Zelikina T.I. 1997. The caudal gland in the cat is a hepatoid gland. Izv. Akad. Nauk. Ser. Biol. s/v:556-570.

Shabadash S.A. \& Zelikina T.I. 2002. Once more about hepatoid circumanal glands of dogs: History of their discovery and reasons for revision the structural and functional data. Izv. Akad. Nauk. Ser. Biol. $\mathrm{s} / \mathrm{v}: 176-185$.

Sokolov V.E. \& Shabadash S.A. 1979. Histochemical characteristics of the anal sacs of the cat. Biol. Bull. Acad. Sci. USSR 6:751-763.

Sokolov V.E., Shabadash S.A. \& Zelikina T.I. 1980. Innervation of eccrine sweat glands. Biol. Bull Acad. Sci. USSR 7:331-346.

Sokolov V.E., Shabadash S.A. \& Zelikina T.I. 1981. Innervation of the apocrine sweat glands. Biol. Bull. Acad. Sci. USSR 8:242-254.

Souza T.M. 2005. Estudo retrospectivo de 761 tumores cutâneos em cães. Tese de Mestrado, Universidade Federal de Santa Maria, Camobi, Santa Maria, RS. 281p.

Scott D.W., Miller D.H. \& Griffin C.E. 2001. Muller and Kirk's Small Animal Dermatology. 6th ed. Saunders, Philadelphia. 1528p.

Scott D.W. 1980. Feline dermatology 1900-1978: A monograph. J. Am. Anim. Hosp. Assoc. 16:331.

Sternberg, S.S. 1997. Histology for Pathologist. 2nd ed. Lippincott-Raven, Philadelphia. 1200p.

Urmacher C.D. 1997. Normal skin, p.25-45. In: Sternberg S.S. (Ed.), Histology for Pathologist. 2nd ed. Lippincott-Raven, Philadelphia. 1200p.

Webb A.J. \& Calhoun M.L. 1954. The microscopic anatomy of the skin of mongrel dogs. Am. J. Vet. Res. 15:274-280.

Werner J. 2008. Padrões dermatohistopatológicos no diagnóstico dermatológico. Clin. Vet. 13:38-42.

Yager J.A. \& Scott D.W. 1993. The skin and appendages, p.531-738. In: Jubb K.V.F., Kennedy P.C. \& Palmer N. (Ed.), Pathology of Domestic Animals. Vol.1. 4th ed. Academic Press, San Diego. 780p.

Yager J.A. \& Wilcock B.P. 1994. Color Atlas and Text of Surgical Pathology of the Dog and Cat: Dermatopathology and skin tumors. Wolfe, London. 320p. 